\title{
A cross- sectional study to assess the knowledge regarding stem cells and its transplantation among students from various colleges \& women from anc clinic in Indore
}

\author{
Yesikar V. ${ }^{1}$, Banseria R. ${ }^{2 *}$, Dixit S. ${ }^{3}$, Shivram G. ${ }^{4}$ \\ DOI: https://doi.org/10.17511/ijphr.2016.i4.04
}

\footnotetext{
1 Veena Yesikar, Associate Professor, Department of Community Medicine, MGM Medical College, Indore, Madhya Pradesh, India.

2* Ruchita Banseria, Resident, Department of Community Medicine, MGM Medical College, Indore, Madhya Pradesh, India.

3 Sanjay Dixit, Professor \& Head, Department of Community Medicine, MGM Medical College, Indore, Madhya Pradesh, India.

${ }^{4}$ Geeta Shivram, Demonstrator, Department of Community Medicine, MGM Medical College, Indore, Madhya Pradesh, India.
}

Introduction: Stem cell transplantation (SCT) is a life-saving procedure for a number of malignant and non-malignant life-threatening diseases. Umbilical cord blood (UCB) which was thought to be as waste material earlier, is considered now a valuable thing. It is an important source of hematopoietic stem cells. A stem cell transplant is the infusion of healthy cells to replace diseased or damaged ones. Material and Method: This was a Cross- sectional study conducted on 80 undergraduate medical students \& 80 non-medical students and 40 Antenatal mothers. The study tool for data collection in the form of a Structured Questionnaire was designed. Study was conducted for a period of two months. Data was analysed in SPSS version 20, Chi-Square test was used to assess the significance of the responses and a $\mathrm{P}$ value $<0.05$ was considered statistically significant. Results: $45 \%$ medicos and $31.25 \%$ non medicos were aware of the terminology stem cell while only $10 \%$ Antenatal mothers knew about it. Monetary Reason was the major factor which prevented $77.5 \%$ mothers from opting for stem cell preservation while12.5\% Antenatal mothers never thought of it, 7.5\% Antenatal mothers did not opt because of social stigma and $2.5 \%$ due to Ethical consideration. Conclusion: Students from streams other than Medicine and antenatal mothers should be educated about the advances being made in Medical Science and a brief introduction about the newer modalities of treatments, to increase people participation and achieving a Holistic Approach towards Health Care.

Keywords: Antenatal mothers, Medical students, Non-medical students, Stem cell transplantation (SCT)

Corresponding Author

Ruchita Banseria, Resident, Department of Community Medicine, MGM Medical College, Indore, Madhya Pradesh, India.

Email: ruchibanseria@gmail.com
How to Cite this Article

To Browse

Yesikar V, Banseria R, Dixit S, Shivram G. A crosssectional study to assess the knowledge regarding stem cells and its transplantation among students from various colleges \& women from anc clinic in Indore. Public Health Rev Int J Public Health Res. 2016;3(4):156-161.

Available From

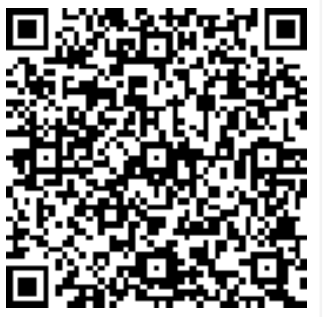

https://publichealth.medresearch.in/index.php/ijphr/ article/view/46

Manuscript Received 2016-06-26

Conflict of Interest No

Review Round 1
2016-07-06
Funding
Nil

Review Round 2
2016-07-24
Ethical Approval
Yes

Review Round 3

Plagiarism X-checker $7 \%$
Accepted 2016-08-05

Note

(c) 2016 by Veena Yesikar, Ruchita Banseria, Sanjay Dixit, Geeta Shivram and Published by Siddharth Health Research and Social Welfare Society. This is an Open Access article licensed under a Creative Commons Attribution 4.0 International License https://creativecommons.org/licenses/by/4.0/ unported [CC BY 4.0]. 


\section{Introduction}

Stem cell transplantation (SCT) is a life-saving procedure for a number of malignant and nonmalignant life-threatening diseases [1]. Umbilical cord blood (UCB) which was thought to be a waste material earlier, is considered now a valuable thing. As it is an important source of hematopoietic stem cells, a stem cell transplant is the infusion of healthy cells to replace diseased or damaged ones.

If successful, the healthy replacement stem cells will integrate into the body and give rise to more cells that can all take on the necessary functions of a specific tissue. Umbilical Cord Blood also contains stem cells that can differentiate into other types, such as cartilage, fat, hepatic, cardiac, and neural cells, fuelling speculation about the use of cord blood stem cells for regenerative medicine. More than 40,000 SCTs are being performed annually worldwide [2].

In India, progress has been slow and the number of transplants performed till now is around 500 [2]. The procedure itself has many technical variations according to the primary disease, age of the patient, facilities available, and experience of the centre. In terms of cost effectiveness, a SCT performed early is more beneficial than conventional treatment with eventually fatal results.

In India, the largest potential load of patients are those suffering from thalassemia major. In this condition, allogeneic SCT is the only form of cure, and is clearly cost effective compared to conventional blood transfusions and iron chelation Therapy. Chronic myeloid leukaemia (CML) is potentially curable with allogeneic SCT, and the cost per added year of life is much less than with drugs like interferon.

In multiple myeloma, autologous SCT is now a standard therapy [2]. The facilities for SCT in India are increasing at acceptable rate but focus needs to done on increasing awareness of its optimal utilization $[3,4]$. This study has been done with an objective to find out the awareness regarding stem cells, knowledge about regenerative medicine and tissue replacement after injury or disease in students from medical and non - medical profession, and to know the difference of knowledge among two groups, and to know about the knowledge, attitude and expectation of Ante-natal mothers regarding the same.

\section{Materials and Methods}

This was a Cross- sectional study conducted on 80 undergraduate medical students of MGM Medical College, Indore, 80 non-medical undergraduates from GSITS, IPS, College of Management, Agriculture College, Indore and 40 Antenatal mothers from M.Y Hospital. A qualitative protocol was used in order to provide a current knowledge, which involved data collection through a detailed opinion-questionnaire administered across the colleges.

The study tool for data collection in the form of a "Structured Questionnaire" was designed to elicit information on demographic and psychographic aspects of the respondents. Study was conducted for a period of two months. The Psychographic variables included attitude towards Stem Cell Transplant. The questionnaire was constructed on the basis that most questions reflected the knowledge and attitude towards stem cell transplant, banking, and Regenerative medicine and health services. Most questions consisted of 4 responses and some 3 or 5 responses.

The responses thus obtained were then compiled, processed and analysed to arrive at the opinion on various issues. The responses obtained were analysed with respect to the variables of age, profession and socioeconomic status. Those who are interested in the study were included and written consent was taken from them. Regarding ethical consideration permission was taken from the respective colleges and hospital. Data was analysed in SPSS version 20; Chi-Square test was used to assess the significance of the responses and a $P$ value $<0.05$ was considered statistically significant.

\section{Results}

Table-1: On hearing about the term Stem Cells what comes in their mind-

\begin{tabular}{|l|l|l|l|l|}
\hline \multirow{2}{*}{\multicolumn{1}{c|}{ Option }} & \multicolumn{2}{c|}{ Medicos } & \multicolumn{2}{c|}{ Non-medicos } \\
\cline { 2 - 6 } & No. & $\%$ & No. & $\%$ \\
\hline A)Stem Cell banking & 21 & 26.3 & 2 & 27.5 \\
\hline B)Stem cell transplant & 36 & 45 & 25 & 31.25 \\
\hline C)Medical Procedure & 22 & 27.5 & 21 & 26.25 \\
\hline D)Nothing & 1 & 1.29 & 12 & 15 \\
\hline Total & 80 & 100 & 80 & 100 \\
\hline
\end{tabular}

As per this table $45 \%$ medico and $31.25 \%$ non medicos were aware of the term stem cell in transplantation. 
Undergraduate Medical students had a better understanding about Stem Cells i.e. $98.75 \%$ followed by students of Non-medical stream i.e. $87.5 \%$

\section{Figure-1: What is the source of information} regarding the terminology (stem cells?)

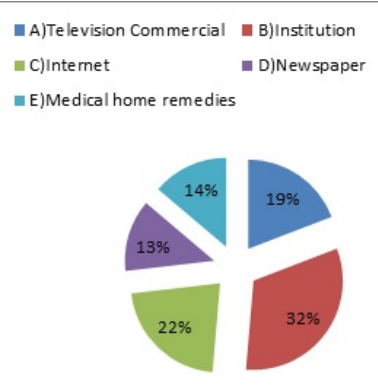

Table- 2: Preservation of the umbilical cord

\begin{tabular}{|l|l|l|l|l|}
\hline \multirow{2}{*}{ Option } & \multicolumn{2}{|c|}{ Medicos } & \multicolumn{2}{c|}{ Non-medicos } \\
\cline { 2 - 6 } & No. & $\%$ & No. & $\%$ \\
\hline A)Yes & 71 & 88.75 & 41 & 51.25 \\
\hline B)No & 4 & 5 & 2 & 2.5 \\
\hline C)Not aware & 2 & 2.5 & 11 & 13.75 \\
\hline D)as per doctors consult & 3 & 3.75 & 26 & 32.5 \\
\hline Total & 80 & 100 & 80 & 100 \\
\hline
\end{tabular}

Most of the population was in favour of stem cell preservation comprising of $89 \%$ medicos and $52 \%$ non-medicos. $87.5 \%$ Medicos knew that stem cells are preserved at stem cell bank while according to $48.75 \%$ non-medicos were aware that stem cells were preserved at all the given facilities i.e. Health care centre, Super speciality hospital and Stem cell bank.

Table-3: Who can be a Donor of stem cell transplant -

\begin{tabular}{|l|l|l|l|l|l|l|}
\hline \multirow{2}{*}{ Option } & \multicolumn{2}{|c|}{ Medicos } & \multicolumn{2}{|c|}{$\begin{array}{c}\text { Non- } \\
\text { medicos }\end{array}$} & Total & Percentage \\
\cline { 2 - 8 } & No. & $\%$ & No. & $\%$ & No. & $\%$ \\
\hline $\begin{array}{l}\text { A)Any individual } \\
\text { related/unrelated }\end{array}$ & 53 & 66.25 & 18 & 22.5 & 71 & $44.375 \%$ \\
\hline B)Identical twins & 3 & 3.75 & 15 & 18.75 & 17 & $10.625 \%$ \\
\hline C)Blood Donor & 1 & 1.25 & 15 & 18.75 & 16 & $10 \%$ \\
\hline D)Patient(himself/herself) & 20 & 25 & 27 & 33.75 & 47 & $29.375 \%$ \\
\hline E)None & 3 & 3.75 & 5 & 6.25 & 8 & $5 \%$ \\
\hline Total & 80 & $100 \%$ & 80 & $100 \%$ & 160 & $100 \%$ \\
\hline
\end{tabular}

As per this table maximum Medicos i.e. $66.25 \%$ believed that donor can be any individual related/unrelated whereas maximum non-medicos i.e. $33.75 \%$ believed it to be patient himself.
Medical students have a better knowledge about it as compared to non-medical students.

\section{Figure- 2: Uses of stem cells:}

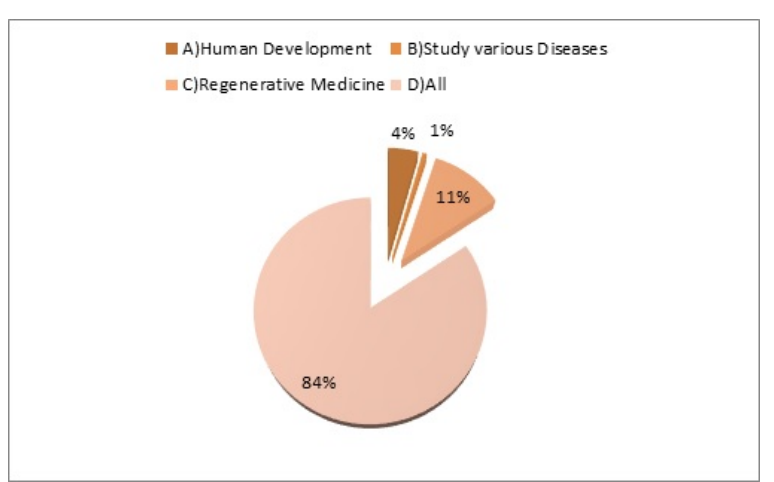

Figure shows $84 \%$ of study subjects had knowledge that stem cells were used in all the 3 domains while $4 \%$ thought of human development and $11 \%$ thought of various diseases.

Table 3: Indications of Stem cell transplant

\begin{tabular}{|l|l|l|l|l|l|l|}
\hline \multirow{2}{*}{ Option } & \multicolumn{2}{|c|}{ Medicos } & \multicolumn{2}{|c|}{ Non-medicos } & \multirow{2}{*}{ Total } & Percentage \\
\cline { 2 - 5 } & No. & $\%$ & No. & $\%$ & & \\
\hline A)Anaemia & 1 & 1.25 & 2 & 2.5 & 3 & $1.875 \%$ \\
\hline B)Thalassemia & 4 & 5 & 16 & 20 & 20 & $12.5 \%$ \\
\hline C)Cancer & 5 & 6.25 & 11 & 13.75 & 16 & $10 \%$ \\
\hline D)All & 70 & 87.5 & 51 & 63.75 & 121 & $75.625 \%$ \\
\hline Total & 80 & $100 \%$ & 80 & $100 \%$ & 160 & $100 \%$ \\
\hline
\end{tabular}

As per this table majority of the medicos i.e. $87.5 \%$ and non-medicos i. e. $63.75 \%$ believed that stem cell transplant can be a therapy for majority of chronic illnesses like Anaemia, Thalassemia and Cancer but the medical students had a better understanding as revealed by putting the chi-square test and the result was statistically significant. $70 \%$ Medicos believes that Stem cell therapy is effective over conventional therapy while $48.5 \%$ non-medicos were not sure whether stem cell therapy was better than conventional therapy.

Antenatal Mothers: $80 \%$ of Antenatal mothers had a good understanding of the term. Only $35 \%$ expecting mothers had an idea of the origin of stem cells. $75 \%$ Antenatal mothers believed that stem cells can be derived from foetus, adults or umblical cord. Amongst Antenatal mothers Women 22.5\% recollected stem cell banking and $17.5 \%$ it as a medical procedure, $72.5 \%$ believed that stem cell transplant can be a therapy for majority of chronic illnesses like Anaemia, Thalassemia and Cancer. $50 \%$ Antenatal mothers also believed in preserving it. 
$80 \%$ of Antenatal mothers had a good understanding of the term. $40 \%$ Antenatal mothers also believed that stem cells are preserved at all the given facilities i.e. Health care centre, Super speciality hospital and Stem cell bank.

Maximum ANC mothers i.e. 52.5\% were not sure whether stem cell therapy was better than conventional therapy. $85 \%$ ANC mothers did not opt this method in their current pregnancy while 7.5 percent opted.80\% Antenatal mothers would opt for stem cell preservation if they get a chance while $12.5 \%$ denied of preserving the stem cells.

However $7.5 \%$ were not sure about it. Monetary Reason was the major factor which prevented $77.5 \%$ mothers from opting for stem cell preservation while $12.5 \%$ Antenatal mothers never thought of it, $7.5 \%$ Antenatal mothers did not opt because of social stigma and $2.5 \%$ due to Ethical consideration. $36 \%$ of total population including $55 \%$ ANC first come across the term stem cells from television commercial.

\section{Discussion}

Stem cells have the ability to build every tissue in the human body. Hence, they have great potential for future therapeutic uses in tissue regeneration and repair. Personal or private storage of stem cell banking has expanded worldwide, which seems to provide a type of biological insurance to their children which will secure their future. Thus a basic awareness amongst medical and non-medical undergraduates and antenatal mothers was assessed and also the interactive session utilized for imparting relevant information [5].

In our study it was found that Undergraduate Medical students had the better understanding about Stem Cells i.e. $98.75 \%$ followed by students of Non-medical stream i.e. $87.5 \%$ which is quite high as compare to study done in nursing students in Malaysia[6]and form study done in dental practitioner in Rajasthan [7], the reason for this discrepancy can be the difference in year of conduction of the study. Over the years definitely knowledge has increased.

$63.75 \%$ undergraduates from non medical stream believed that stem cell transplant can be a therapy for majority of chronic illnesses like Anaemia, Thalassemia and Cancer. This seems to be fairly good percentage and also draws attention to the fact that youths are concerned with knowledge not only in their field but also exploring other issues.
More than $80 \%$ of medical students considered it to be a life saving procedure.

With this concept in mind these students will surely think of stem cell storage in the future years. Nevertheless, with the moderate knowledge possessed by the undergraduate students, they can foresee the power and the future of stem cells in the medical application; thus, they possess a positive attitude for acquiring more information and exposure about the benefits of stem cells.

$87.5 \%$ Medical students know that stem cells are preserved at stem cell bank while only $48.75 \%$ nonmedicos thought so. This much difference is not very alarming because the basic knowledge of medical students over the years might have contributed to their correct response.

\section{Antenatal mothers}

In total the average knowledge of antenatal women was fairly good this was higher than was seen in other studies from Canada and Europe[8,9]. This high percentage could be because of the bias in choosing sample as antenatal women as they are continuously exposed to medical fraternity. So they might have gained this knowledge during some interactive session. Conducting this study with different sample might yield different results.

$85 \%$ ANC mothers in our study did not opt this method in their current pregnancy while $7.5 \%$ opted which is much less as compared to study done in Australia [10]. Financial disparity in countries demographic profile might be responsible for it.

Nearly half of the ANC mothers came across someone who had opted for Stem cell therapy; of these $30 \%$ of them were friends, $17.5 \%$ were family members and $12.5 \%$ were distant relatives. This shows that there might be an increase in number of females opting for cord preservation in coming years. $80 \%$ ANC mothers would opt for stem cell preservation if they get the chance while $12.5 \%$ denied of preserving the stem cells .However $7.5 \%$ are not sure about it.

Monetary Reason is stopping maximum number of ANC mothers i.e. $77.5 \%$ to opt for stem cell preservation followed by $12.5 \%$ ANC mothers who had never thought of it, $7.5 \%$ ANC mothers do not opt because of social stigma and $2.5 \%$ because of ethical issues. The cost of banking involved was the main reason for people not availing it. 
Frenandez et al also believed that the cost of private cord blood banking would need to drop substantially to influence the preference for public banking [8]. So the two strongest factors that influenced an unwillingness to preserve UCB were the high cost and concerns regarding the safety of the preservation as said in study by Lu et al [11]. In our study $80 \%$ of Antenatal mothers have the knowledge though Maria et al which said that the level of knowledge is low (31\%) [12].

\section{Conclusion}

So in our study on we conclude that most of the medical students have knowledge about stem cell transplant and preferred it over conventional therapies. Even students from other streams, though less in number have a brief knowledge about it and they too preferred it over conventional methods. The result of the present study suggest that even though most of the students (medical and other) have faith in stem cell transplant and banking yet monetary reasons continue to be a major drawback.

As it is shown that UCB cells have their unique qualities and potential, and so consequently UCB banks might dramatically increase the scope of their clinical application [13]. Stem cell therapy and Regenerative Medicine are the future of Modern medicine. They might in future become the conventional form of treatment for the conditions where stem cell therapy is the only form of cure. Cost-cutting (providing at a subsidized rate) for the therapy will bring a revolution in the field of regenerative medicine.

Government should make an amendment to make Stem cell Banking compulsory and free of cost for all the families having a history of hereditary diseases and the families where the first born has any congenital anomaly. In India, the first public UCB repository became functional in early 2000[14]. However since then time has not advocated expected progress in this field of utmost public importance.

More resources should be allocated by the Government to the newer practices in Medicine like Regenerative Medicine, Stem Cell Transplant \& Stem Cell Banking especially when they are the only form of cure available. Students from streams other than Medicine should be educated about the advances being made in Medical Science and a brief introduction about the newer modalities of
Treatments along with the conventional ones should be added in Higher Secondary Education/Junior Colleges in order to sensitize them about the already established along with Emerging Health Care Facilities, to increase people participation and achieving a Holistic Approach towards Health Care.

\section{Reference}

01. Armitage JO. Bone marrow transplantation. N Engl J Med. 1994;Mar 24;330(12)827-38.

[Crossref]

02. R Kumar. Stem Cell Transplantation- Indian Perspective. Journal Indian Academy of Clinical Medicine. 2002;3(2)182-8.

[Crossref]

03. George B, Mathews V, Srivastava V, Srivastava $A$, Chandy $M$. Tuberculosis among allogeneic bone marrow transplant recipients in India. Bone Marrow Transplant. 2001; May;27(9)973-5. [Crossref]

04. Saikia TK, Advani SH, Parikh PM, Bapna A, Som jee S, Mukhopadhyay A, Gopal R, Nair CN. Resul ts of allogeneic bone marrow transplant in chron ic myeloid leukaemia following conditioning with busulfan and cyclophosphamide. J Assoc Physicians India. 1999 Aug;47(8)770-3. [Crossref]

05. McKenna D, Sheth J. Umbilical cord bloodcurrent status \& promise for the future. Indian J Med Res. 2011 Sep;134;261-9.

[Crossref]

06. Jee Leng LYE, Lean Keng SOON, Wan Amir Nizam WAN AHMAD, Suat Cheng TAN. Knowledge and Attitude about Stem Cells and Their Application in Medicine among Nursing Students in Universiti Sains Malaysia, Malaysia. Malays J Med Sci. 2015 Jul-Aug;22(4)23-31. [Crossref]

07. Ankita Goyal. Knowledge, awareness and attitude regarding stem cells among dental practitioners in udaipur city, rajasthan. International Journal of Advanced Research. 2015;3(2)677-684.

[Crossref]

08. Fernandez CV, Gordon K, Van den Hof M, Taweel $\mathrm{S}$, Baylis F. Knowledge and attitudes of pregnant women with regard to collection, testing and banking of cord blood stem cells. CMAJ. 2003 Mar 18;168(6)695-8.

[Crossref] 
09. Katz G, Mills A, Garcia J, Hooper K, McGuckin C, et al. (2011) Banking cord blood stem cells: attitude and knowledge of pregnant women in five European countries. Transfusion. 2011 Mar;51(3)578-86.

doi: $10.1111 /$ j.1537-2995.2010.02954.x [Crossref]

10. Ryan J Hodges, Nadia Bardien, Euan Wallace. Acceptability of Stem Cell Therapy by Pregnant Women. Birth. 2012 Jun;39(2)91-97.

DOI: $10.1111 /$ j.1523-536X.2012.00527 [Crossref]

11. Lu $H$, Chen $Y$, Lan $Q$, Liao $H$, Wu J, Xiao $H$, Dickerson CA, Wu $\mathrm{P}$, Pan $\mathrm{Q}$. Factors That Influence a Mother's Willingness to Preserve Umbilical Cord Blood- A Survey of 5120 Chinese Mothers. Plos One. 2015 Dec.

[Article] [Crossref]
12. Screnci M, Murgi E, Pirrè G, Valente $E$, Gesuiti $P$, Corona F, Girelli G. Donating umbilical cord blood to a public bank or storing it in a private bank- knowledge and preference of blood donors and of pregnant women. Blood Transfus. 2012 Jul;10(3)331-337. doi: $10.2450 / 2012.0081-11$ [Crossref]

13. Bojanić I, Golubić Cepulić B. Umbilical cord blood as a source of stem cells. Acta Med Croatica. 2006 Jun;60(3)215-25. [Crossref]

14. Viswanathan C, Kabra P, Nazareth V, Kulkarni M, Roy A. (2009) India's first public cord blood repository-looking back and moving forward. Indian Journal of Hematology and Blood Transfusion. 2009 Sep;25(3)111-117.

doi: $\quad 10.1007 / \mathrm{s} 12288-009-0023-5 \quad$ [Crossref] 